Patil, S. R., Merrick, S., and Lubs, H. A. (1971). Identification of each human chromosome with a modified Giemsa stain. Science, 173, 821-822.

Raoul, O., Rethoré, M. O., Dutrillaux, B., Michon, L., and Lejeune, J. (1975). Trisomy 14q partielle. I. Trisomie 14 partielle par translocation maternelle $\mathrm{t}(10 ; 14)(\mathrm{p} 15,2 ; \mathrm{q} 22)$. Annales de Génétique, 18, 35-39.

Rethoré, M. O., Dutrillaux, B., and Lejeune, J. (1973). Translocation $46, \mathrm{XX}, \mathrm{t}(15,21)(\mathrm{q} 13 ; \mathrm{q} 22,1)$ chez la mère de deux enfants atteints de trisomie 15 et de monosomie 21 partielles. Annales de Génétique, 16, 271-275.

Webb, G. C., Garson, M., Robson, M. K., and Pitt, D. B. (1971). A partial D-trisomy/normal mosaic female. Fournal of Medical Genetics, 8, 522-527.

\section{Larsen syndrome in two generations of an Italian family}

Summary. This paper describes a familial case of Larsen syndrome. Typical anomalies were present in the propositus and 2 of his 6 daughters. In addition, all patients had progressive deafness and the 2 daughters had cleft palate. The certain exclusion of any consanguinity between the couple, suggests, in this instance, the dominant mode of transmission of the syndrome.

The association of multiple congenital joint dislocations with characteristic facies is known as Larsen syndrome (Larsen, Schottstaedt, and Bost, 1950). The main clinical findings include: flattened face with depressed nasal bridge, anterior dislocation of the tibia, bilateral dislocation of hips and elbows, and deformities of feet and hands. Mental development as well as the result of a number of laboratory studies are normal. To date, more than 20 instances have been reported, some of them having minor variations of the classical picture (Lee, 1973).

We have studied a family from Southern Italy in which 2 children and their father were affected. This is, to our knowledge, the only severe male case known to have transmitted the full syndrome to his children.

\section{Case reports}

The pedigree of the family is shown in Fig. 1. The propositus (III.8) was a 54-year-old man, height $135 \mathrm{~cm}$. He was the last of 4 sibs, the product of a consanguineous mating. None of his sibs had any deformity: however, one member of the kindred was affected by deafness (I.5) and another one by progressive blindness and deafness (III.1). Our patient married a normal woman who certainly could not be consanguineous, because she came from another city, about $400 \mathrm{~km}$ away. They had 6 children, all females, and the last two, 12 years and 7 years of age, respectively, had the same deformities as their father (Fig. 2).

Briefly, they all presented the complete picture of Larsen syndrome: flattened face with hypertelorism, strabismus, antimongoloid palpebral fissures, low set ears, scapho-oxycephaly; bilateral joint dislocations of hips, elbows, knees, and deformities of feet and hands. In addition, there was progressive deafness and cleft palate in the two daughters. Radiological examinations showed the typical congenital joint dislocations of the hips, knees, elbows, as well as abnormalities of the skull (scaphooxycephaly), synostosis of some tarsal bones, and metacarpophalangeal subluxations. Biochemical data and chromosome analyses were normal. Mental development was normal.

\section{Discussion}

Our observations are consistent with a diagnosis of Larsen syndrome: in fact, such diagnosis may be posed whenever there are at least two main features -that is characteristic flattened face and congenital joint dislocation (Silverman, 1972). Though having the full-blown picture, the severity was nevertheless different among the three subjects: while the propositus and his older daughter were able to walk, but with some difficulty, the other daughter who was 7 years old, was unable even to stande This is consistent with the well-known variability of expresssivity of the gene (Latta et al, 1971).

As regards the mode of inheritance of the syndrome, most observations are consistent with auto-

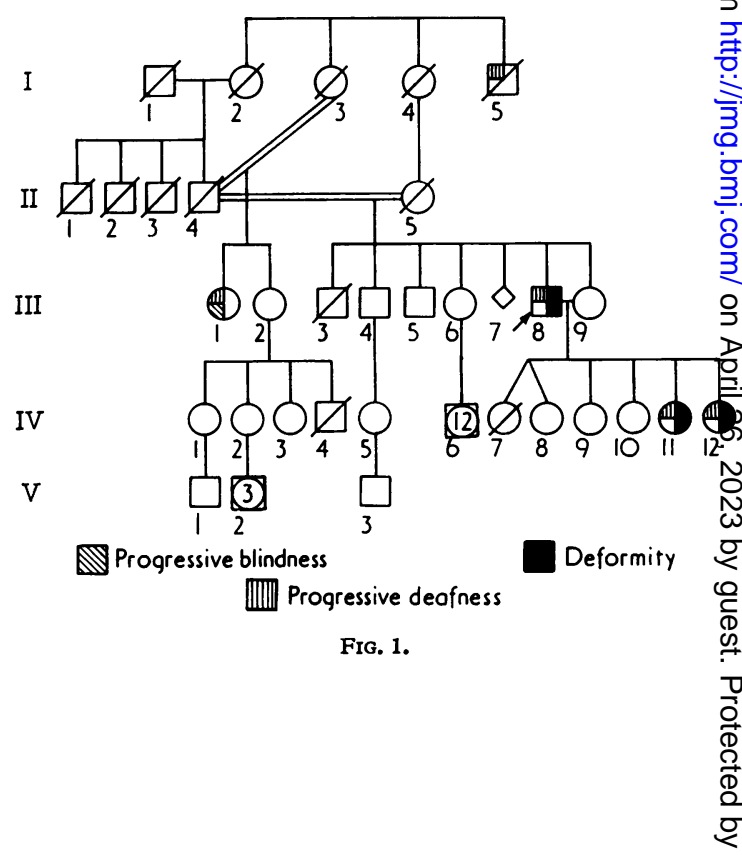




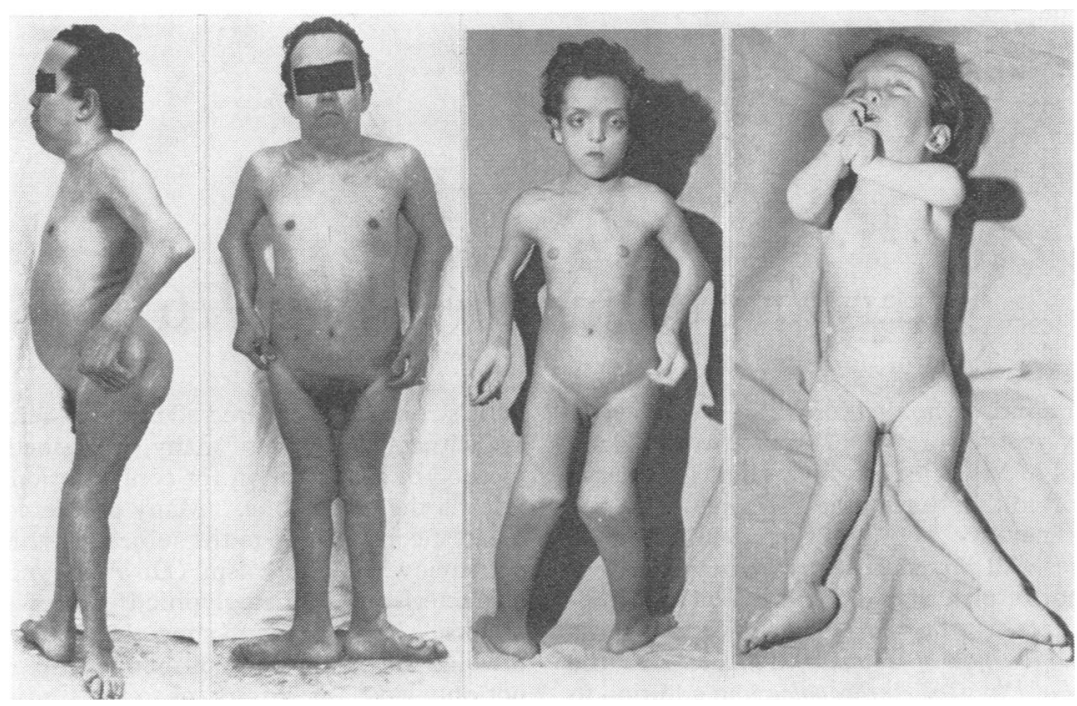

FIG. 2.

somal recessive inheritance (McKusick, 1971; Cohen, 1974), but the possibility of a dominant mode of transmission has also been suggested in three families. In the case by Latta et al (1971), the diagnosis in the mother of the propositus remains uncertain, because she had only a saddle nose, which developed after being hit by a tennis-ball. The report by McFarlane (1947) is more convincing, in that a woman with low nasal bridge, congenital dislocation of both knees, and hyperextension of both elbows, produced three affected children, each by a different mate, all of whom had bilateral knee dislocation. In the family reported by Harris and Cullen (1971), a mother, her daughter, and possibly the mother's father were all affected.

Our observation might suggest the dominant inheritance of Larsen syndrome in this instance (in this case, the syndrome must have arisen as a new mutation in the germ cells of one of the parents of III.8). However, because the subject III.8 was the offspring of a consanguineous marriage, we cannot rule out the possibility that he was a homozygote for the condition, and that his wife III.9 was a heterozygote carrier (the absence of the syndrome among the four sibs of III.8 can be regarded as favouring this possibility).

Acknowledgement is made to Dr. R. M. Bannerman, Medical Genetics Unit, Buffalo General Hospital, for his advice.

\section{Ventruto, B. Festa, L. Sebastio, and G. Sebastio}

Dipartimento di Ematologia degli Ospedali Riuniti di Napoli, Servizio di Immunopatologia e Genetica Ematologica. Italy

\section{Catani}

Divisione di Ortopedia e Traumatologia degli Ospedali Riuniti di Napoli, Italy

\section{REFERENCES}

Cohen, M. M., Jr. (1974). Cleft palate, flattened facies, and multiple congenital dislocations, In Birth Defects. Atlas and Compendium, p. 266. National Foundation-March of Dimes, New York.

Harris, R. and Cullen, C. H. (1971). Autosomal dominant inheritance in Larsen's syndrome. Clinical Genetics, 2, 87-90.

Larsen, L. J., Schottstaedt, E. R., and Bost, F. C. (1950). Multiple congenital dislocations associated with characteristic facial abnormality. Fournal of Pediatrics, 37, 574-581.

Latta, R. J., Graham, C. B., Aase, J., Scham, S. M., and Smith, D. W. (1971). Larsen's syndrome: a skeletal dysplasia with multiple joint dislocations and unusual facies. Fournal of Pediatrics, 78, 921-298.

Lee, P. A. (1973). Multiple joint dislocations and peculiar facies. American fournal of Diseases in Children, 126, 828-830.

McFarlane, A. L. (1947). A report of four cases of congenital genu recurvatum occurring in one family. British fournal of Surgery, 34, 388-391.

McKusick, V. A. (1971). Mendelian Inheritance in Man, 3rd ed., p. 436. Johns Hopkins Press, Baltimore.

Silverman, F. N. (1972). Larsen's syndrome: congenital dislocation of the knees and other joints, distinctive facies, and, frequently, cleft palate. Annales de Radiologie, 15, 297-328. 